\title{
Peran Kegiatan Fun cooking dalam Kemampuan Sosial Emosional dan Bahasa Anak
}

\author{
Yosi Amaros ${ }^{1}$, Rohita $^{2}$ \\ ${ }^{1,2}$ Pendidikan Anak Usia Dini, Fakultas Psikologi dan Pendidikan, Universitas Al-Azhar Indonesia, \\ Komplek Masjid Agung Al-Azhar Jl. Sisingamangaraja, Jakarta Selatan, 12110
}

Penulis untuk Korespondensi/E-mail: rohita@uai.ac.id

\begin{abstract}
Abstrak - Penelitian ini bertujuan untuk mengetahui peran fun coooking dalam meningkatkan kemampuan sosial emosional dan bahasa anak di TK Al Izhar Pondok Labu, Jakarta Selatan. Subjek penelitian ini anak usia 5-6 tahun yang mengikuti kegiatan ekstra kurikuler fun cooking berjumlah 8 orang anak. Metode yang digunakan adalah pendekatan kualitatif deskriptif dengan teknik pengumpulan data menggunakan observasi, wawancara, dan dokumentasi. Kemudian data yang sudah terkumpul di triangulasi dengan jenis triangulasi teknik. Berdasarkan hasil penelitian anak, diperoleh informasi bahwa fun cooking memiliki peran dalam kemampuan sosio emosional dan bahasa anak. Kegiatan fun cooking memiliki peran dalam kemampuan bahasa anak terutama dalam memahami beberapa perintah secara bersamaan; menjawab pertanyaan yang lebih kompleks; memperkaya perbendaharaan kata; serta menuliskan nama sendiri. Sementara dalam kemampuan sosial emosional anak, fun cooking membuat anak mampu menaati aturan kelas; mengatur diri sendiri; berbagi dengan orang lain; menunjukkan sikap toleran; serta mengekspresikan emosi yang sesuai dengan kondisi yang ada.
\end{abstract}

Abstract - This study aims to determine the role of fun cooking in improving emotional social skills and language of children in kindergarten Al Izhar Pondok Labu, South Jakarta. These research subjects 56 years old children who take part in extracurricular fun cooking amounted to 8 children. The method used is descriptive qualitative approach with data collection technique using observation, interviews, and documentation. Then the data that have been collected in triangulation with the type of triangulation techniques. Based on the results of the study of children, there was information that the fun of cooking has a role in the socio-emotional and language abilities of children. Fun cooking activities have a role in the child's language ability, especially in understanding multiple commands simultaneously; answer more complex questions; enriching vocabulary; as well as write his own name. While the emotional social abilities of children, fun cooking to make children able to obey the rules of the classroom; self-regulating; share with others; show tolerance; and express the emotions that correspond to existing conditions.

Keywords - Fun cooking, Language skills, Social emotional skills

\section{PENDAHULUAN}

nak usia dini adalah sosok individu yang
sedang menjalani suatu proses perkembangan
dengan pesat untuk tahap perkembangan
selanjutnya. Pada masa ini proses pertumbuhan dan
perkembangan dalam berbagai aspek sedang
mengalami masa yang cepat dalam rentang
perkembangan hidup manusia. Aspek
perkembangan anak yang dikembangkan di Taman
Kanak - Kanak meliputi moral dan nilai agama, sosio emosional, bahasa, kognitif, fisik motorik dan seni.

Agar aspek-aspek tersebut bisa tercapai dengan optimal maka diperlukan adanya stimulasi. Menurut Moersintowati (2002), stimulasi yaitu perangsangan dan latihan-latihan terhadap kepandaian anak yang datangnya dari lingkungan di luar anak. Berbagai macam stimulasi dapat dilakukan di rumah maupun di sekolah. Stimulasi yang diberikan di rumah oleh orangtua merupakan 
stimulasi yang melibatkan anggota keluarga dan lingkungan sekitar rumah. Sementara stimulasi yang diberikan kepada anak di sekolah, dilakukan dengan bimbingan guru salah satunya di lembaga Taman Kanak-kanak (TK). Usia TK adalah usia anak yang berada pada rentang usia 4-6 tahun, yang terbagi menjadi 2 kelompok usia, yaitu usia 4-5 tahun dan usia 5-6 tahun.

Usia 5-6 tahun berbeda karakteristik dan kemampuan dengan anak usia 4-5 tahun, termasuk pada kemampuan sosial emosional dan bahasa. Kenyataan yang diperoleh berdasarkan observasi di beberapa sekolah diketahui bahwa anak usia 5-6 tahun belum memiliki kematangan dalam emosinya. Hal ini terlihat seperti anak yang suka terburu-buru dalam menyelesaikan tugas, tidak teliti dalam penyelesaiannya serta tidak dapat bersabar saat menunggu giliran. Demikian pula halnya dalam kemampuan berbahasa. Tidak semua nak usia 5-6 tahun memiliki perbendaharaan kata yang cukup sehingga proses komunikasi kurang berjalan lancar. Hal lain rendahnya kemampuan berbahasa juga disebabkan oleh kurangnya pengalaman anak sehingga anak tidak dapat bercerita karena tidak ada yang dapat diceritakan.

Berbagai metode dan kegiatan telah dilakukan guru di dalam kelas, namun belum memberikan pencapaian yang optimal. Salah satu sekolah yang terletak di wilayah Jakarta Selatan, yaitu TK Al Izhar Pondok Labu, memiliki cara yang berbeda. Sekolah memberikan sebuah kegiatan ekstra kurikulum yang bernama fun cooking.

Memasak adalah proses agar makanan menjadi matang, dengan memilih dan mengombinasikan bahan-bahan menggunakan alat dan metode yang luas. Salah satu sekolah yang menerapkan kegiatan memasak yaitu sekolah TK Al Izhar Pondok Labu, Jakarta. Di sekolah tersebut kegiatan memasak merupakan kegiatan ekstrakurikuler pilihan anak yang dinamakan dengan fun cooking. Kegiatan fun cooking merupakan kegiatan dimana anak dapat mencoba langsung membuat makanan dari bahan yang mentah hingga menjadi matang melalui proses-proses dan bimbingan guru.

Berdasarkan uraian tersebut maka diperlukan sebuah kegiatan penelitian yang bertujuan untuk:

1. Mengetahui peran fun cooking dalam kemampuan sosial emosional anak

2. Mengetahui peran fun cooking dalam kemampuan bahasa anak

\section{Kemampuan Sosial Emosional dan Bahasa Anak Usia 5-6 Tahun}

Anak usia 5-6 tahun memiliki kemampuan berbahasa yang lebih baik dibandingkan usia sebelumnya. Pada usia ini anak sudah menguasai 1500 kosa kata atau lebih dan bahkan sudah bercakap-cakap seperti orang dewasa serta banyak bertanya. Kemampuan berbahasa menjadi sarana anak untuk berbicara, mendengarkan, membaca dan menulis dalam proses kegiatan belajarnya. Hal ini seperti yang diungkapkan oleh Suhartono (2005: 13) bahwa peranan bahasa bagi anak usia dini diantaranya sebagai sarana untuk berpikir, sarana untuk mendengarkan, sarana untuk berbicara dan sarana agar anak mampu membaca dan menulis.

Berdasarkan Standar Tingkat Pencapaian Perkembangan yang terdapat di dalam Peraturan Menteri Pendidikan Nasional kemampuan yang harus dicapai pada anak usia 5-6 tahun pada aspek bahasa diantaranya yaitu mengerti beberapa perintah secara bersamaan, memahami aturan dalam suatu permainan, menjawab pertanyaan yang lebih kompleks, memiliki lebih banyak kata-kata untuk mengekspersikan ide pada orang lain, melanjutkan sebagian cerita/dongeng yang telah diperdengarkan, dll.

Sementara pada kemampuan Sosio-emosional anak usia 5-6 tahun biasanya menyukai persahabatan, sering mempunyai dua atau tiga teman bahkan lebih untuk bermain, berbagi dengan orang lain, mengatur diri sendiri, mengikuti petunjuk dan menjanlakan tugas hampir setiap waktu, biasanya melakukan apa yang diminta orangtua dan guru. Perkembangan sosiol emosional pada anak merupakan perkembangan dimana anak dikenalkan dengan lingkungan luar seperti lingkungan masyarakat, lingkungan sekolah, lingkungan rumah sehingga anak harus bisa menyesuaikan diri dengan lingkungan sekitarnya.

Sutirna (2013: 118) menyatakan bahwa perkembangan sosial merupakan proses pemerolehan kemampuan untuk berperilaku yang sesuai dengan keinginan yang berasal dari dalam diri seseorang yang sesuai dengan tuntunan dan harapan-harapan sosial yang berlaku dalam masyarakat. Berdasarkan STPPA, disajikan kemampuan sosial emosional dan bahasa yang akan diamati dalam kaitannya dengan kegiatan fun cooking 
Tabel 1. Tingkat Pencapaian Perkembangan Anak (TPPA)

\begin{tabular}{|c|c|}
\hline $\begin{array}{c}\text { Lingkup } \\
\text { Perkembangan } \\
\text { Bahasa }\end{array}$ & $\begin{array}{l}\text { Tingkat Pencapaian } \\
\text { Perkembangan Anak }\end{array}$ \\
\hline $\begin{array}{l}\text { Bahasa } \\
\text { a. Memahami } \\
\text { Bahasa } \\
\text { b. Mengungkapkan } \\
\text { Bahasa }\end{array}$ & $\begin{array}{l}\text { Memahami beberapa } \\
\text { perintah secara } \\
\text { bersamaan. } \\
\text { Menjawab } \\
\text { pertanyaan yang } \\
\text { lebih kompleks. } \\
\text { Memperkaya } \\
\text { perbendaharaan kata. }\end{array}$ \\
\hline c. Keaksaraan & $\begin{array}{l}\text { Menuliskan nama } \\
\text { sendiri. }\end{array}$ \\
\hline $\begin{array}{l}\text { Sosio-emosional } \\
\text { a. Rasa tanggung } \\
\text { jawab untuk diri } \\
\text { sendiri dan } \\
\text { oranglain }\end{array}$ & $\begin{array}{l}\text { Menaati aturan kelas } \\
\text { (kegiatan, aturan). } \\
\text { Mengatur diri } \\
\text { sendiri. }\end{array}$ \\
\hline \multirow[t]{2}{*}{ b. Perilaku Sosial } & $\begin{array}{l}\text { Berbagi dengan } \\
\text { orang lain. } \\
\text { 1. Menunjukan } \\
\text { sikap toleran. }\end{array}$ \\
\hline & $\begin{array}{l}\text { 2. Mengekspresikan } \\
\text { emosi yang sesuai } \\
\text { dengan kondisi } \\
\text { yang ada (senang- } \\
\text { sedih-antusias } \\
\text { dsb). }\end{array}$ \\
\hline
\end{tabular}

\section{Fun cooking}

Kata Fun cooking terdiri dari 2 kata, yaitu fun yang mengandung makna menyenangkan dan cooking yang berarti memasak. Menurut Marwati dkk (2002: 70), memasak merupakan kegiatan mempersiapkan bahan, peralatan yang digunakan, sampai proses pengolahan sampai bahan makanan siap untuk dimakan. Sehingga jika dua kata tersebut digabungkan, makna yang tersirat dari kata fun cooking adalah kegiatan memasak yang menyenangkan.

Fun cooking adalah sesuatu hal yang menyenangkan sama halnya saat anak memakan makanan yang sudah jadi namun kali anak terlibat juga dalam proses pembuatan makanannya tersebut. Kebanyakan anak sangat bersemangat saat mendapat kesempatan untuk melakukan tugas-tugas yang nyata, bukan berpura-pura dalam melakukannya, tetapi benar-benar melakukan. Hal ini sesuai pendapat Schuett (dalam Mualirakhman,
2013: 47) yang mengungkapkan bahwa, memasak bisa menjadi aktivitas yang menyenangkan dan bermanfaat.

Saat kegiatan memasak, diperlukan kemampuan mempersiapkan bahan dan peralatan yang akan dibuat. Hal yang perlu diperhatikan dalam kegiatan memasak adalah langkah kegiatan memasak. Pertama, menyiapkan bahan-bahan yang dibutuhkan dan harus sesuai dengan apa yang ingin disajikan. Kedua, kegiatan memasak, dan ketiga, adalah mengetahui cara penyajian memasaknya.

Kegiatan fun cooking merupakan kegiatan yang membutuhkan kolaborasi antara guru dan anak dalam setiap tahapannya. Dimulai dengan berdiskusi antara guru berdiskusi dengan anak untuk mengetahui apa saja yang ingin dilakukan saat kegiatan memasak, makanan apa saja yang akan dibuat, serta proses apa saja yang akan dilakukan saat kegiatan memasak. Menurut Appleton and McCrea (2001: 29) terdapat lima tahap dalam kegiatan fun cooking yaitu mengumpulkan informasi, menentukan tujuan, mengidentifikasi segala hambatan dan kemungkinan, membuat perencanaan, dan refleksi atas kegiatan yang terjadi.

Memilih peralatan memasak juga harus diperhatikan. Peralatan memasak harus yang aman seperti mangkuk yang kuat dan tidak mudah pecah, pisau bergerigi plastik, sendok dan garpu plastik, serta wadah yang terbuat dari plastik, pinggiran meja yang tumpul, dan lain sebagainya. Hal ini dilakukan untuk mengurangi resiko bahaya dalam memasak. Peralatan yang diperlukan dalam kegiatan fun cooking ada beberapa macam. Dodge dan Colker (2001: 282), menuliskan bahwa peralatan untuk memasak yaitu: sendok takar plastik, mangkuk plastik, tongkat penggiling (rolling-pin), sendok karet (spatula), cetakan kue kering, kertas kue, loyang muffin, loyang kue, kuas, alat pemeras jeruk, pengupasan kulit sayuran, sendok kayu, corong, alat kawat pengocok telur (wire whisk), penjepit, pengayak, pisau plastik atau pisau untuk mengoles yang terbuat dari stainless, gelas ukur, parutan keju, gunting, dan talenan.

Seperti kegiatan lainnya, kegiatan fun cooking juga dievaluasi untuk mengetahui ketercapaian dari tujuan yang diharapkan. Evaluasi yang dilakukan pada kegiatan fun cooking sama halnya seperti evalausi di TK dan dilaksanakan berdasarkan gambaran atau deskripsi pertumbuhan dan perkembangan anak serta unjuk kerja peserta didik 
yang diperoleh menggunakan berbagai teknik penilaian. Teknik evaluasi yang dilakukan pada kegiatan pembelajaran di TK terdiri dari dua macam teknik (Trianto, 2011: 103), yaitu:

a. Tes. Tes standar terdiri dari tes intelegensi, minat, bakat, kepribadian atau yang lainnya.

b. Non Tes. Metode ini digunakan dengan bantuan alat-alat penilaian non tes. Alat penilaian non tes yang sering digunakan di TK yaitu pemberian tugas, percakapan, observasi, catatan anekdot, skala penilaian, unjuk kerja, hasil karya, portofolio dan penilaian diri sendiri.

\section{METODOLOGI PENELITIAN}

Berdasarkan permasalahan yang peneliti kaji, yaitu tentang Peran Fun cooking Dalam Kemampuan Sosial Emosional dan Bahasa Anak Usia 5-6 Tahun, maka penelitian ini menggunakan metode penelitian kualitatif. Pendekatan yang peneliti gunakan adalah pendekatan kualitatif deskriptif. Menurut Moleong (2011: 11) Pendekatan kualitatif deskriptif adalah data yang dikumpulkan berupa kata-kata, gambar, dan bukan angka.

Penelitian dilakukan di Taman Kanak-kanak Al Izhar Pondok Labu, Jalan RS Fatmawati Kav.49 Kelurahan Pondok Labu Kecamatan Cilandak Subjek Penelitian. Adapun subjek penelitian terdiri atas 8 (delapan) anak yang mengikuti ekskul fun cooking, 1 (satu) orang wakil kepala sekolah, 2 (dua) orang guru ekskul fun cooking, dan 3 (tiga) orang guru kelas TK B1, B2, dan B3.

Data yang dibutuhkan dikumpulkan dengan metode Wawancara bentuk terstruktur, Observasi bentuk partisipasi aktif, dan Dokumentasi. Sementara analisis data yang digunakan pada penelitian ini adalah analisis data di lapangan model Miles and Hubermen dimana aktivitas dalam analisis data kualitatif dilakukan secara interaktif dan berlangsung secara terus menerus sampai tuntas, sehingga datanya sudah jenuh. Aktivitas dalam data meliputi reduction, display, dan conclusion drawing/verification. (Sugiyono, 2011: 247).

Keabsahan data dilakukan dengan meneliti kredibilitasnya menggunakan teknik triangulasi. Adapun jenis triangulasi yang dipilih ialah triangulasi teknik. Hal ini dikarenakan melalui triangulasi teknik data yang sudah di dapat bisa dilakukan pengecekan terhadap kesesuaian dari ketiganya, yaitu kesesuaian data antara hasil wawancara dengan keadaan yang terjadi di lapangan (hasil dari pengamatan/observasi) serta data yang di dapat dari studi dokumentasi.

\section{HASIL DAN PEMBAHASAN PENELITIAN}

\section{Hasil Penelitian}

TK Al Izhar Pondok Labu ialah sebuah lembaga pendidikan Taman Kanak-Kanak yang berada dibawah naungan Yayasan Anakku. Perguruan Islam Al Izhar Pondok Labu (PIIPL) berdiri pada 11 Maret 1987. Program pendidikan PIIPL dimulai dengan dibukanya Taman Kanak-Kanak (TK) pada Juli 1987.

Pelaksanaan kegiatan fun cooking di TK Al Izhar Pondok Labu dilakukan setiap hari Rabu pukul 11.00-12.00. Pada Rabu minggu pertama, kegiatan yang dilakukan adalah membuat salad buah, pada hari itu kegiatan dimulai pukul 11.00. Pada Rabu minggu kedua, kegiatan yang pukul 11.00. Pada Rabu minggu ketiga, kegiatan yang dilakukan adalah membuat bakwan makaroni. Pada Rabu minggu terahir yaitu minggu keempat, kegiatan yang dilakukan adalah membuat kue kelepon.

\section{Proses Pelaksanaan Fun cooking Salad Buah}

Pada hari Rabu minggu pertama, kegiatan yang dilakukan adalah membuat salad buah. Kegiatan dimulai pukul 11.00 yang diawali dengan mencuci tangannya kemudian anak duduk ditempat masingmasing dan guru memberikan alat-alat masak seperti talenan, pisau, dan piring secara estafet. Kemudian guru ikut duduk dan memimpin doa sebelum memulai kegiatan, dan dilanjutkan dengan mengabsen anak. Setelah guru mengabsen anak, guru langsung membahas atau menjelaskana menu yang akan dibuat, dengan posisi berdiri dan posisi anak tetap duduk di kursi. Kemudian guru menjelaskan dibarengi dengan pertanyaanpertanyaan seperti "Hari ini kita akan membuat salad buah, ada yang tahu salad buah?". Ada 2 (dua) anak yang menjawab dengan jawaban yang berbeda "biasanya aku suka beli salad buah di pizza hut sama bunda", dan anak yang lain mengatakan "aku pernah bikin bu guru kalo mamah lagi libur katanya biar buang air besarnya lancar".

Kemudian guru menjelaskan bahan-bahan apa saja untuk membuat salah buah. Guru menjelaskan tetap dengan posisi berdiri dan sambil menunjukan bahan yang akan digunakan "ada buah-buah seperti apel, 
melon, anggur, dan strawbery, ada juga yogurt, susu dan keju". Ketika guru menjelaskan ada anak yang bertanya "ibu guru yogurth aku berbeda dengan yang ini" lalu kemudian ibu guru mengambilnya dan ternyata ada anak yang membawa yogurt cair dan ada yang membawa yogurt seperti cream "diperhatikan yah..ditangan kanan ibu ada yogurt cair dan ditangan kiri ibu ada yogurt berbentuk krim jadi lebih padat teksturnya, nanti setelah kita mengiris buahbuahnya kita coba yah... lebih cocok menggunakan yougerth yang cair atau yogerth crim".

Selesai menjelaskan, guru membantu mengupas kulit melon dan kulit apel yang cukup keras. Lalu kemudian guru memotong buah melon dan apel menjadi beberapa bagian. Selanjutnya guru menugaskan anak untuk mengiris buah. Ada anak yang mengiris melon, strawberry, apel, anggur, dan ada juga anak yang memarut keju. Keju tersebut nantinya akan ditaburkan di atas buah.

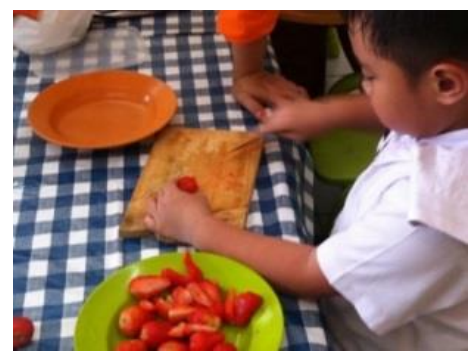

Gambar 1. Anak mengiris strawberry

Setelah buah tersebut diiris, guru menyiapkan 7 (tujuh) piring untuk menaruh masing-masing buah yang sudah diiris tersebut. Hal ini bertujuan untuk membantu anak membedakan jenis buah dan rasa. Setelah piring terisi semua dengan buah, guru memberikan tempat makan plastik yang nantinya akan digunakan untuk membawa pulang salad buah setelah anak menuliskan namanya masing-masing pada wadah makan plastik tersebut.

Ketika semua anak mendapatkan piring plastik, anak-anak diminta mengambil buah tersebut secara bergiliran atau antri.

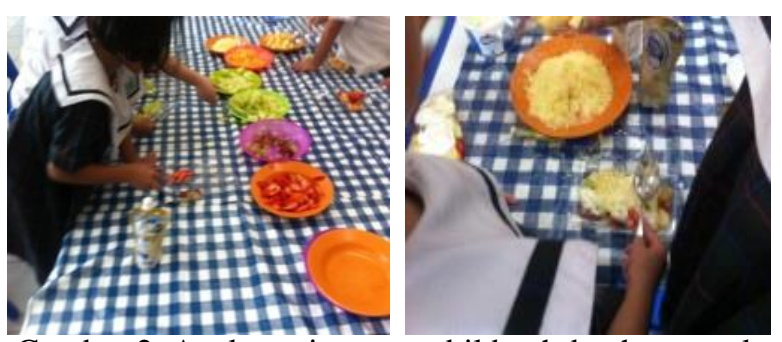

Gambar 2. Anak antri mengambil buah-buahan untuk membuat salad
Sebelum buah tersebut diberi yogerth, guru mencoba di depan anak-anak. Yogurt manakah yang lebih cocok untuk salad "perhatikan ya anakanak bu guru akan coba nih.. yogurt yang mana yang cocok untuk salad buah ini, kita coba yaaa... bu guru pertama mau mencoba dengan yogurt cair ini dulu kemudian baru dengan yogurt crim, bismillahirohmanirrohiim.." setelah guru mencoba yogurt cair ternyata salad yang dihasilkan terlihat seperti sup karena yogurt cair berubah menjadi seperti kuah. Kemudian ketika guru memberi salad dengan krim yogurth ternyata hasilnya seperti mayonase.

Setelah melakukan percobaan, anak-anak mengantre untuk mengambil buah dan memberi yougerth, susu, dan keju pada buah tersebut.

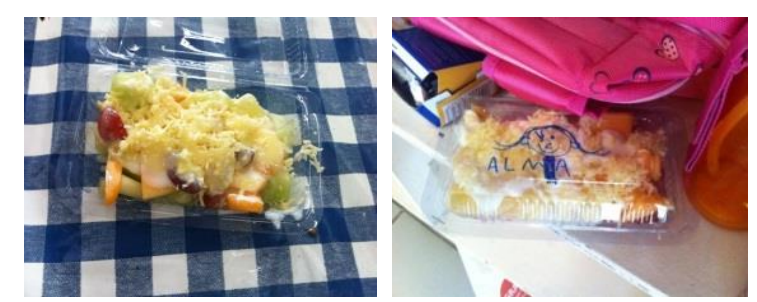

Gambar 3. Hasil kerja anak dan nama anak di atas wadah plastik

Anak secara tertib mengikuti peraturan guru. Setelah selesai anak membereskan alat-alat memasaknya seperti mencuci talenan, pisau dan piringnya. Selanjutnya anak secara tertib duduk di tempatnya masing-masing dan kegiatan tersebut ditutup dengan membaca hamdallah "Alhamdulillaahh..."

\section{Pancake}

Di Rabu minggu kedua, kegiatan yang dilakukan adalah membuat pancake. Pada hari itu kegiatan dimulai pukul 11.00. Sebelum anak memulai kegiatan anak terlebih dahulu mencuci tangannya kemudian anak duduk ditempat masing-masing dan guru memberikan alat-alat masak seperti talenan, pisau, piring secara estafet kepada anak. Lalu kemudian guru ikut duduk dan memimpin doa sebelum memulai kegiatan dan mengabsen anak. kegiatan selanjutnya adalah membahas atau menjelaskan menu yang akan dibuat dalam posisi berdiri.

Guru menjelaskan menu yang akan dibuat sambil memberikan pertanyaan-pertanyaan seperti "hari ini kita akan membuat pancake, yang di dalamnya isi pisang dan coklat keju, ada yang sudah pernah coba belum?", seorang anak menjawab dengan 
"aku belum pernah buattt... tapi aku pernah dibawain pancake sama ayah". Pada kegiatan memasak ini guru ikut serta dalam membuat adonannya. Kemudian setelah itu guru menjelaskan bahan-bahan yang akan dibuat "naahh...ini anakanak bisa lihat yaa bahan-bahan untuk membuat pancake ada tepung terigu, susu, telur, air, garam, gula, baking powder, pisang ambon, keju dan coklat, coklat yang dipakai adalah coklat cokicoki”.

Setelah itu guru juga menjelaskan cara membuat adonannya, karena membuat pancake harus menggunakan api maka guru ikut serta dan juga mengawasinya. "Nanti yang akan membuat adonan disini ibu guru yaaa, nanti anak-anak yang membantu menganduk adonan dengan mixer yaaa.. pertama bu guru akan membuat adonannya yaitu memasukan terigu, kemudian telur, garam dan gula serta air lalu kita aduk dengan menggunakan mixer". Kemudian guru juga mempraktekkan cara memotong pisangnya "pisangnya diiris agak ke samping yaaaa, boleh juga bulat-bulat".

Saat guru membuat adonan, semua anak memperhatikan, dan ada anak yang bertanya "buиuu.. kenapa aduknya menggunakan mixer, kenapa tidak menggunakan tangan saja?”, guru menjawab "kalau menggunakan mixer hasilnya akan lebih cepat hanya 5 menit saja adonan sudah mengental, nanti kita buktikan yaaa..”. Saat guru membuat adonan, anak mengiris pisang dan ada juga yang memarut keju. Saat anak membuka kulit pisang anak-anak langsung membuangnya ke tempat sampah. Saat adonan sedang diolah dengan mixer setiap anak dipanggil satu per satu untuk mencoba mengaduk adonan dengan mixer.

Saat mengaduk banyak yang tertawa dan merasa aneh karena baru pertama kali memegang mixer menyala, "ibuuи..tangan aku geliiii soalnya mixernya geterrr ya buuu”, "ibuuu..mixernya cepet banget yah muternya", "ibuu..liat deh tangan aku sampe ikut getarrr". Banyak sekali ungkapan perasaan anak saat memegang mixer.

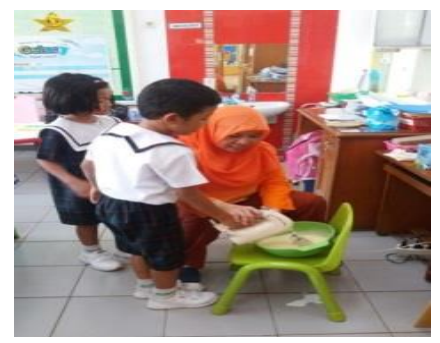

Gambar 4. Anak menggunakan mixer untuk membuat adonan
Setelah adonannya jadi, adonan dimasak dengan menggunakan teflon dan ketika adonan berubah kecoklatan, diangkat kemudian diletakkan di atas piring. Ketika adonan matang, guru memberi perintah untuk menaruh beberapa irisan pisang, dan taburan keju serta coklat coki-coki. Guru menjelaskan sambil mempraktikan di depan anak.
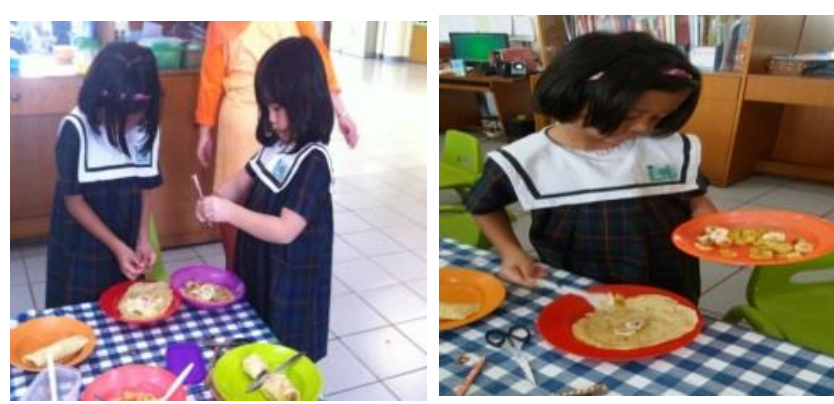

Gambar 5. Anak membuat pancake

Pancake yang sudah dingin dimasukkan ke dalam wadah plastik yang sudah disediakan dan kemudian anak memberi nama di atas wadah plastik tersebut.

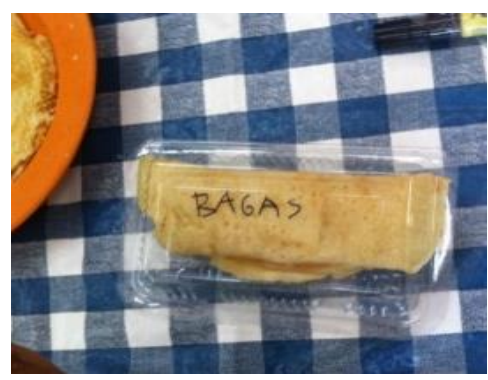

Gambar 6. Pancake milik Bagas

Setelah kegiatan selesai anak-anak membereskan peralatan memasak yang telah digunakan seperti mencuci talenan, piring, sendok, dan pisau, serta pengaduk mixer, tak lupa membuang sampahsampahnya ke tempat sampah

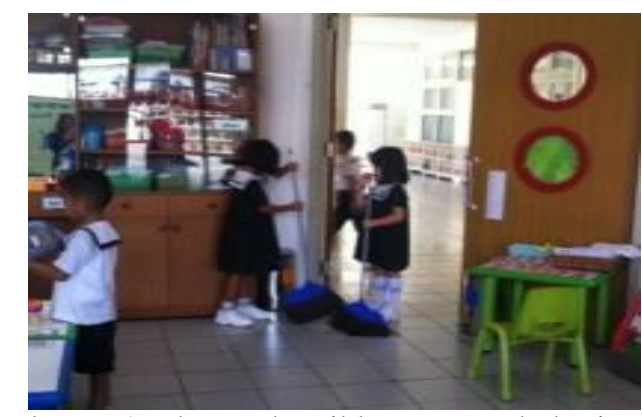

Gambar 7. Anak membersihkan tempat bekerjanya 
Setelah semua kegiatan selesai, semua anak duduk rapih, dan ditutup dengan membaca hamdallah "alhamdulillahhh..".

\section{Peran Kegiatan Fun cooking dalam Pengembangan Kemampuan Sosial Emosional dan Bahasa \\ Untuk melihat peran kegiatan fun cooking dalam pengembangan kemampuan sosial emosional dan bahasa anak usia 5-6 tahun, digunakan tabel di bawah yang berdasarkan pada STPPA.}

Tabel 2. Tingkat Pencapaian Perkembangan Anak

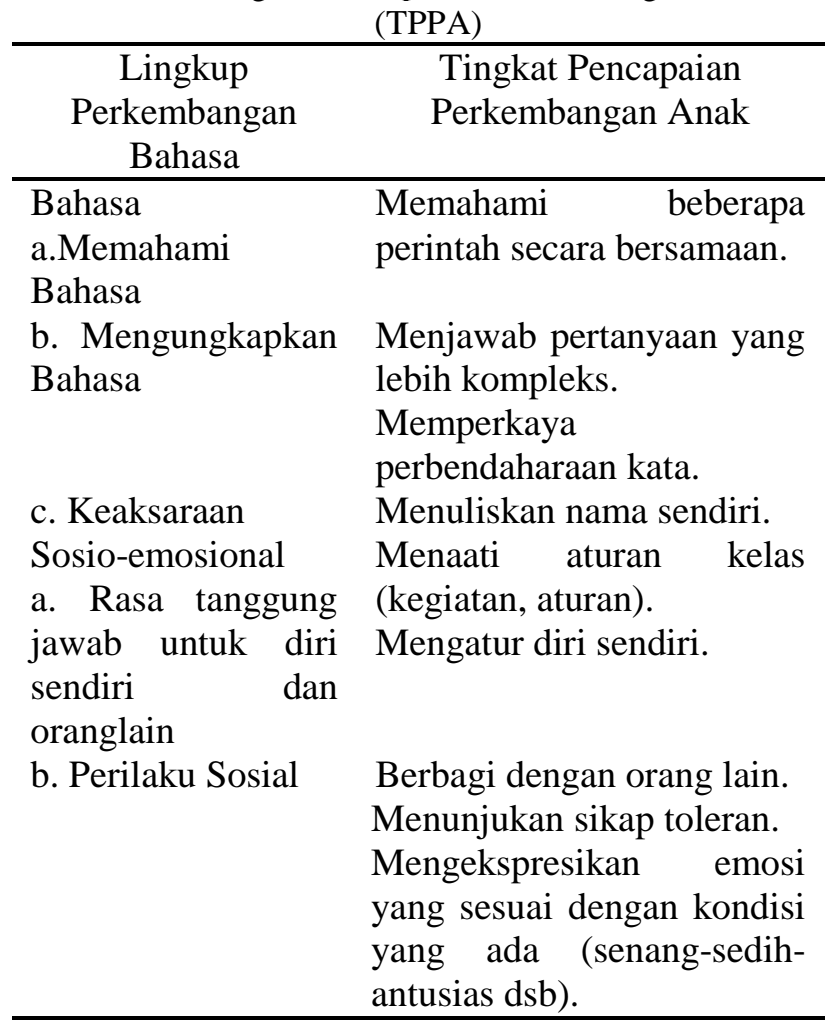

Berdasarkan tabel di atas dapat dikatakan bahwa kemampuan bahasa anak dalam hal memahami beberapa perintah secara bersamaan dibentuk ketika anak diminta untuk melakukan kegiatan membuat salad secara berurutan, dimulai dengan mengambil bermacam-macam buah, menghiasnya dengan susu, keju, dan yogurt dengan membentuk antrian.

Kemampuan menjawab pertanyaan yang lebih kompleks dapat terlihat pada saat anak dapat menjawab dengan menyebutkan kembali bahanbahan makanan yang digunakan untuk membuat salad buah maupun pancake. Anak juga dapat menyebutkan langkah-langkah dalam membuat makanan yang akan dipraktekkan hari itu.
Sementara untuk memperkaya perbendaharaan kosa kata anak, anak dikenalkan dengan berbagai kata-kata baru sesuai dengan peralatan memasak yang digunakan hari itu, seperti sendok takar plastik, mangkuk plastik, tongkat penggiling (rolling-pin), sendok karet (spatula), cetakan kue kering, kertas kue, loyang muffin, loyang kue, kuas, alat pemeras jeruk, pengupasan kulit sayuran, sendok kayu, corong, alat kawat pengocok telur (wire whisk), penjepit, pengayak, pisau plastik mixer, talenan, teflon, dan sebagainya. Anak juga dikenalkan dengan kata-kata yang terkait dengan bahan makanan yang digunakan seperti bawang putih bubuk, baking powder, adonan, taburan, irisan, pisang ambon, dll. Selain itu, anak juga dapat menuliskan namanya sendiri pada wadah plastik tempat makanan yang akan dibawanya pulang.

Sementara untuk kemampuan sosial emosional, rasa tanggung jawab untuk diri sendiri dan orang lain ditunjukkan anak dengan menaati aturan kelas (kegiatan, aturan). Sebagai contoh, anak tahu bahwa kulit pisang adalah bagian yang tidak digunakan untuk membuat pancake sehingga harus dibuang di tempat sampah. Kemudian, anak juga membersihkan kembali peralatan masak yang telah digunakan.

Rasa tanggung jawab juga ditunjukkan dengan kemampuan anak mengatur diri sendiri saat mengambil buah-buahan untuk membuat salad tanpa berdesakan atau mendorong temannya hanya agar dapat membuat salad yang pertama. Anak sabar untuk mendapatkan gilirannya. Masingmasing anak diminta untuk mengiris buah-buahan yang berbeda sebagai bahan makanan penyusun salad. Anak juga melakukan kegiatan memotong atau mengiris buah-buahan dengan sabar dan hatihati agar hasil potongan sesuai dengan apa yang diperintahkan oleh guru. Selain itu, anak juga tidak ada yang berusaha untuk memakan pancake sebelum pancake tersebut dihidangkan. Anak juga bersabar menunggu giliran untuk mengaduk adonan dengan mixer pada saat membuat pancake.

Memiliki perilaku sosial sebagai salah satu perkembangan sosial yang harus dimiliki anak ditunjukkan dengan kemampuan anak untuk berbagi. Hal ini terlihat saat anak tidak mengambil buah, keju, yogurth maupun susu secara berlebihan, karena ada teman yang lain yang menginginkan hal yang sama dengan dirinya. Kemampuan tersebut juga menunjukkan sikap toleran yang dimiliki anak. 
Melalui kegiatan fun cooking, tanpa rasa takut dan malu anak mengungkapkan apa yang ia rasakan, seperti ketika anak merasakan tangannya bergetar saat memegang mixer yang digunakan untuk membuat adonan. Hal tersebut menunjukkan anak melalui fun cooking anak mampu mengekspresikan emosi yang sesuai dengan kondisi yang ada. Hal ini terlihat saat anak mengemukakan apa yang ia rasakan saat memegang mixer yang sedang bekerja. Anak juga terlihat antusias untuk menyelesaikan semua tugas yang diberikan seperti memotong buah-buahan maupun mengaduk adonan untuk pancake.

\section{Pembahasan Hasil Penelitian}

Berdasarkan hasil penelitian, diketahui bahwa kegiatan fun cooking memberikan kesempatan kepada anak untuk meningkatkan kemampuan sosial emosional dan juga kemampuan bahasanya. Dalam hal berbahasa, anak dapat memperoleh berbagai informasi yang terkait dengan memasak, baik mengenai peralatan memasak, menu masakan hingga cara pengolahan dan penyajiannya. Anak juga mampu apa yang ia ketahui saat ditanya mengenai hal yang akan dimasak, serta mampu mengungkapkan apa yang ia rasakan saat mengolah masakan. Hal ini seperti yang dikatakan oleh Suhartono (2005: 13) bahwa peranan bahasa bagi anak usia dini diantaranya sebagai sarana untuk berpikir, sarana untuk mendengarkan, sarana untuk berbicara dan sarana agar anak mampu membaca dan menulis.

Sementara terkait dengan kemampuan sosial emosional, seluruh anak mampu menciptakan situasi yang kondusif pada saat memasak. Tidak ada anak yang berebut untuk melakukan atau mendapatkan sesuatu jika belum saatnya atau belum gilirannya. Semua kegiatan dikerjakan dengan hati-hati terutama pada saat memotong buah-buahan dan memarut keju. Sehingga semua anak dapat menikmati salad buah dan pancake buatan mereka dengan rasa senang. Hal ini sesuai dengan apa yang disampaikan Sutirna (2013: 118) bahwa perkembangan sosial merupakan proses pemerolehan kemampuan untuk berperilaku yang sesuai dengan keinginan yang berasal dari dalam diri seseorang yang sesuai dengan tuntunan dan harapan-harapan sosial yang berlaku dalam masyarakat. Semua yang dilakukan anak dalam kegiatan fun cooking merupakan tuntutan sekaligus harapan dari seluruh anggota kegiatan tersebut dan semua anak mampu menyelesaikannya dengan baik.

\section{KESIMPULAN DAN SARAN}

\section{Kesimpulan}

Berdasarkan hasil penelitian dan pembahasan, maka dapat disimpulkan bahwa:

1. Kegiatan fun cooking memiliki peran dalam kemampuan bahasa anak terutama dalam memahami beberapa perintah secara bersamaan; menjawab pertanyaan yang lebih kompleks; memperkaya perbendaharaan kata; serta menuliskan nama sendiri.

2. Kegiatan fun cooking memiliki peran dalam kemampuan sosial emosional anak terutama dalam menaati aturan kelas; mengatur diri sendiri; berbagi dengan orang lain; menunjukkan sikap toleran; serta mengekspresikan emosi yang sesuai dengan kondisi yang ada

\section{Saran}

Adapun saran yang dapat disampaikan adalah:

1. Untuk mengembangkan kemampuan bahasa anak:

a. Hendaknya guru meminta anak untuk menyebutkan peralatan masak serta bahan apa apa saja yang akan digunakan sesuai dengan apa yang sudah mereka ketahui.

b. Guru meminta anak untuk menuliskan apa saja peralatan memasak yang digunakan, bahan makanan yang akan dimasak, serta cara mengolahnya dengan cara membagi anak menjadi 3 kelompok. Hal ini dilakukan untuk mendukung kemampuan keaksaraan anak. Kegiatan lain yang juga dapat dilakukan adalah meminta anak membacakan menu masakan atau alat-alat masak yang akan digunakan.

c. Guru dapat meminta anak menceritakan kembali apa saja yang anak lakukan atau apa yang anak rasakan dari makanan yang telah mereka buat bersama di depan. Sehingga guru dapat mengetahui kemampuan anak dalam menggunakan kosa kata, sekaligus juga memupuk keberanian anak untuk bercerita di depan banyak orang.

2. Untuk mengembangkan kemampuan sosial emosional anak guru dapat memberi tugas kepada anak untuk secara bergiliran memberikan sesuatu kepada teman-temannya. Sebagai contoh ada anak yang membagikan talenan untuk semua anak, ada anak yang membagikan pisau, ataupun membagikan piring plastik tempat buah. Dengan demikian anak tidak hanya merasa bertanggung jawab atas 
tugas pribadi tetapi juga merasa memiliki tugas kelompok.

\section{DAFTAR PUSTAKA}

[1] Moersintowati, Tumbuh Kembang Anak dan Remaja, Jakarta: Sagung Seto, 2002.

[2] Marwati, dkk, Peningkatan Kompetensi Siswa Sekolah Menengah Kejuruan Melalui Pencapaian Keterampilan Wirausaha Bidang Boga. Jakarta: Gramedia Pustaka Utama, 2007.

[3] J. Appleton, and Nadien McCrea, Do Carrots Make You See Better? A Guide To Food and Nutrition in Early Childhood Programs. Maryland: Gryphon House, 2011.

[4] D. T. Dodge, and L. J. Colker. The Creative Curriculum For Early Childhood, Third Edition. Washington, DC: Teaching Strategies, Inc, 2001.

[5] Suhartono, Pengembangan Keterampilan Bicara Anak Usia Dini, Jakarta: Depdikbud, 2005.
[7] Sutirna, Perkembangan \& Pertumbuhan Peserta Didik. Yogyakarta: Penerbit Andi, 2013.

[8] Trianto, Desain Pengembangan Tematik Bagi Anak Usia Dini TK/RA \& Anak Usia Kelas Awal SD/MI. Jakarta: Kencana Prenada Media Group, 2011.

[9] Permendikbud Nomer 137 Tahun 2014 Tentang Tingkat Pencapaian Perkembangan Anak (TPPA).

[10] D. Setyawati, Upaya Meningkatkan Kreativitas Anak Melalui Fun cooking Di Kelompok B TK Puspasari, Margosari, Pengasih, Kulon Progo, Skripsi: PG PAUD UNY Yogyakarta, 2013.

[11] J. L. Moleong, Metodologi Penelitian Kualitatif. Bandung: Remaja Resdakarya, 2011.

[12] D. Mulyana, Metodologi Penelitian Kualitatif Paradigma Baru Ilmu Komunikasi dan Ilmu Sosial. Bandung: Remaja Rosdakarya, 2010.

[13] Sugiyono, Metode Penelitian Kuantitatif Kualitatif Dan $R \& D$. Bandung: Alfabe, 2011. 